\title{
RISK-ORIENTED APPROACH TO LABOR PROTECTION AT GRAIN PROCESS ENTERPRISES
}

\begin{abstract}
Abstrakt
The article focuses on the introduction of a risk-oriented approach to labor protection at the enterprises of the grain processing industry. Such an approach is imperative in modern conditions in accordance with the Concept of reforming the system of labor protection management. This will involve the introduction of the proactive principle of "preventive actions" (prevention of hazardous events and situations) instead of the existing reactive principle of "corrective actions" (response to hazardous events and situations). A risk-oriented approach to occupational safety and health is the basis for the formation of a new national system for prevention of the operational risks.

In the grain process enterprises, which have agreed their policy on labor protection with international standards, there has been an increase and improvement of the responsibility and competency of the ordinary employees and managers in the safety field, the risk of on-the-job injury has decreased.

Improvement of the system of labor protection and risk management at enterprises should be carried out according to State Standard (DSTU) ISO 31000:2018 "Risk Management. Guidelines (ISO 31000:2018, IDT))". The purpose of the standard is to reduce operational risks to an acceptable level. The main stages of the risk management process are presented.

Identification of hazards, risk assessment, definition of security measures is a constituent and integral part of such a system. This is necessary to identify and understand the dangers that may arise in the course of an enterprise's activity, to assess the risk arising from a particular hazard, and to take measures to reduce the probability of occurrence of hazards.

At the enterprises of the grain process industry, the identification of hazards consists in the definition of all objects, situations or actions (or their combination) that are inherent in an enterprise's activities and present a potential threat to the health and life of workers. At the same time, the different types of works and situations are considered in order to identify the dangers that are constantly present in normal working conditions, as well as the hazards, the impact of which is possible in case of deviation from normal working conditions and emergencies. Examples of possible hazardous factors at such enterprises are given.
\end{abstract}

The adequacy of the existing security measures, the need for their improvement or the introduction of other security measures are determined based on the results of the risk assessment. ational risk

Key words: labor protection, labor protection management system, risk-oriented approach, identification of hazards, oper-

In recent years, the grain process industry, which is an integral part of the grain market of Ukraine, demonstrates its active development. Grain products manufacture volumes (flour, cereals, bran, mixed feed, etc.) and the export of these products grow annually. All this demonstrates the steady increase in production capacity in Ukraine and an increase in the number of jobs in grain process enterprises [1].

Taking into account the current requirements and recommendations of international and European professional organizations in the area of labor protection, all grain process enterprises shall be guided by the basic principles of the international standard OHSAS 18001:2007 "Occupational Health and Safety Assessment Series" or the national version of this standard: DSTU OHSAS 18001:2010 "The Occupational Health and Safety Management System" [2]. It is particularly important to do this now when the Cabinet of Ministers of Ukraine approved the Concept of reforming the labor protection management system in Ukraine and approved a plan of measures for its implementation for 2019-2020 (Order dated 12.12.2018, No. 989-p) [3]. One of the problems that needs to be solved is the current system of labor protection management at all levels, which is formed on the principle of "corrective actions" (reactive principle), i.e. reaction to hazardous events and situations. But there should be the principle of "preventive actions" (proactive), i.e. the prevention of hazardous events and situations. The current approach makes it im- possible to determine the priority of preventive measures for occupational health and safety at each stage of the enterprise's activity. It also does not contribute to the introduction of an effective mechanism for economic incentives for employers to create appropriate, safe and healthy working conditions and prevents employers from choosing the most effective way to manage and integrate an occupational safety and health management system into a general business management system. The heavy regulation of the rules of work execution and the use of machinery and mechanisms has resulted in the accumulation of a significant amount of regulatory and legal acts on occupational safety and health and does not enable the rapid and timely reaction to the rapid development of technologies and economy and is characterized by inefficient use of resources. Due to the lack of an effective analysis of the causes, the measures of response to accidents are directed primarily towards regulation and strengthening of mandatory general requirements without taking into account risk factors in the workplace.

Implementation of the Concept provides for the formation of a new national system for the prevention of occupational risks by introducing a risk-oriented approach in the area of occupational safety and health at the legislative level.

In the European Union, the risk-oriented approach is set forth in Art. 2, 3 of the European Social Charter (revised) [4], as well as the so-called "framework" Directive No. 89/391/EC [5] on the establishment 
of measures to promote the improvement of health and safety of workers. The purpose of the directive is to implement measures to improve the health and safety of workers, i.e. preventive measures. For this purpose, it contains general principles concerning the prevention of occupational risks, assessment of risks that can not be avoided, elimination of sources of risks, adaptation of working conditions to the worker, especially in case of arrangement of the workplaces, the choice of production equipment, working methods, in particular, in order to facilitate the monotonous work and work in the rhythm given by the machine, as well as to reduce the harmful effects of work on health, taking into account gender characteristics; adaptation to technical progress; replacement of the hazardous equipment by safe or less dangerous one, the development of a coherent general risk prevention policy covering equipment, labor organization, working conditions, social relations and the impact of factors associated with the production environment, giving priority to the collective protection measures as to individual protection measures applied by the employee, and proper briefing of employees.

At the modern grain process enterprises, which have agreed their policy on labor protection with international standards, the growth and improvement of the responsibility and competent ordinary employees and managers in the area of security has increased, the risk of onthe-job injuries has decreased.

Improvement of the occupational safety and health management system (OSHMS) at enterprises should be carried out, in the first instance, taking into account the requirements of the national standards DSTU
OHSAS 18001:2010 and DSTU ISO 31000:2018 "Risk management. Guidelines (ISO 31000:2018,IDT)" [6]. The last one was put into effect on January 1, 2019. The goal is to reduce operational risks to an acceptable level. The main stages of the risk management process according to this standard are presented in Table 1.

One of the significant steps in the risk management process is risk assessment, therefore the identification of hazards, risk assessment, and determination of the security measures are constituent and integral part of the OSHMS. Identification of hazards and risk assessment are necessary to identify and understand the hazards that may occur in the course of an enterprise's activities, to assess the risk arising from a particular hazard, and to implement measures to reduce the probability of occurrence of hazards. Today, the provisions on labor protection management system at the power industry enterprises dated 09.02.2015 [7] can be considered one of the best modern OSHMS documents, and therefore it will be useful to study and apply this experience when creating the OSHMS for the grain process industry.

For the identification of hazards and risk assessment on an ongoing basis, each grain process enterprise should have hazard identification and risk assessment methodology aimed at prevention of the incidents, which ensures prioritization, documentation of the risks and use of the necessary safety measures. When developing the hazard identification and risk assessment methodology, it is imperative to take into account the scope of the OSHMS, the nature of possible hazards, the necessary resources, and other factors important for the enterprise. The developed method must necessarily define:

Table 1. The main stages of the risk management process under ISO 31000:2018

\begin{tabular}{|c|c|}
\hline Stage & Stage purpose \\
\hline $\begin{array}{l}\text { I. Information exchange and } \\
\text { counseling }\end{array}$ & $\begin{array}{l}\text { The purpose of the information exchange and counseling is to assist interested } \\
\text { parties in understanding the risks, the basis for making decisions and the reasons for } \\
\text { which certain actions are required. }\end{array}$ \\
\hline $\begin{array}{l}\text { II Definition of the situation } \\
\text { (context) }\end{array}$ & $\begin{array}{l}\text { The purpose of the definition of the context is the adaptation of the risk management } \\
\text { process, which ensures the efficiency and effectiveness of the risk assessment and } \\
\text { the corresponding impact on the risk }\end{array}$ \\
\hline III. Risk assessment & $\begin{array}{l}\text { Risk assessment is a cumulative process of identification, analysis and assessment of } \\
\text { the risk }\end{array}$ \\
\hline IV. Impact on risks & $\begin{array}{l}\text { The purpose of the impact on risk is to select and apply risk-options for impact on } \\
\text { risks. } \\
\text { The impact on risk is an iterative process: } \\
\text { - determination and selection of options for impact on risk; } \\
\text { - planning and implementation of the impact on risk; } \\
\text { - assessment of the effectiveness of such impact; } \\
\text { - making decision on the acceptability of residual risk; } \\
\text { - further impact, if the risk is not acceptable. } \\
\text { The selection of the most appropriate option (s) of impact on risk involves } \\
\text { comparing the costs, efforts and disadvantages of implemention of the chosen mode } \\
\text { of impact with benefits that are obtained through the achievement of the purposes of } \\
\text { the impact on the risk }\end{array}$ \\
\hline V. Monitoring and verification & $\begin{array}{l}\text { The purpose of monitoring and verification is to ensure and improve the quality and } \\
\text { effectiveness of the development, implementation and results of continuous } \\
\text { monitoring and periodic inspections }\end{array}$ \\
\hline $\begin{array}{l}\text { VI. Documentation and } \\
\text { reporting }\end{array}$ & $\begin{array}{l}\text { Documentation of results and feedback. The results of monitoring and verification } \\
\text { should be part of the overall management of the enterprise (organization), } \\
\text { performance appraisal, and reporting }\end{array}$ \\
\hline
\end{tabular}


- responsibilities and powers of the officials, which plan to identify hazards and assess risks, organize the execution of these works, perform these works. Identification of hazards, risk assessment and security measures are carried out by specialists, who have the necessary knowledge about production activities (managers of the subdivisions or sites - heads of departments, masters, technologists, mechanics, electricians, energy workers, experienced workers and other specialists of the enterprise) about the procedure of identification of hazards and risk assessment (specialists of the State Emergency Service);

- procedure for identifying hazards and the methodology for risk assessment and the establishment of necessary security measures;

- forms of documents to be kept during hazard identification and risk assessment, as well as the procedure for their keeping, storage, etc.

When identifying hazards, changes at the enterprise must be taken into account before these changes are introduced. Changes to be taken into account:

- changes in laws or other regulatory acts in the field of labor protection;

- new or changed technological process, new or modified equipment;

- new jobs, new or changed works that are carried out both in the buildings and structures of the enterprise, in the enterprise, outside in the immediate vicinity;

- significant changes in the organizational struc-

ture;

- involvement of other contractors;

- modification of protective devices, equipment or safety measures in the area of labor protection.

Based on the results of the identification of hazards and assessment of the risks associated with the changes, one should identify the occurrence of new hazards due to the introduction of certain changes, and risks associated with these hazards, change of risks associated with other hazards, the need for introduction of other security measures and which ones.

The need for identification of the hazards and risk assessment is also considered if there is a need to determine the effectiveness and adequacy of the security measures implemented; the data of the incident and emergency investigations point to the need for reidentification of hazards and risk re-assessment; detection of inconsistencies during internal audits.

At the enterprises of the grain process industry, the identification of hazards means the definition of all objects, situations or actions (or their combination) that are inherent in the activities of the enterprise and present a potential threat to the health and life of workers. Examples of possible hazardous factors at such enterprises are given in Table 2.

Prior to commence the hazard identification works, it is required to determine the input data, as well as methods and sources of their obtaining. The input data include: protection

- regulatory requirements in the field of labor

- policy in the field of labor protection;

- data on the results of monitoring and measurement of activity indicators in the field of labor pro- tection;

- results of certification of workplaces in terms of labor conditions;

- data on the investigation of incidents;

- results of internal audits, including other management systems, in particular quality management systems, environmental management systems;

- data on the results of preliminary hazard identification and risk assessment;

- data obtained during counseling with workers and stakeholders on occupational safety issues, in particular regarding risks and security measures,

- data on the organization of the workplace, routes of movement;

- technical specifications of products, data on hazardous materials, etc. data can be:

The ways and sources for obtaining of the input

- observation over the regime and methods of work, analysis of the main causes of dangerous situation;

- comparative evaluation (benchmarking);

- interview of specialists as to the processes, equipment, methods of work;

- inspection on labor protection issues;

- analysis of incidents;

- monitoring and evaluation of hazardous influences (chemical and physical factors);

- assessment of the status of works in terms of the possibility of a risk situation;

- documentation on labor protection, in particular regulations, instructions on labor protection;

- drawings, schemes of equipment arrangement, routes of internal transport movement, etc.;

- passports of manufacturers as to equipment, mechanisms, materials, etc.

When identifying dangers at the grain process enterprises, the different types of work and situations are considered in order to identify the dangers that are constantly present in normal working conditions, as well as the hazards, the impact of which is possible in case of deviations from normal working conditions and emergencies.

Thus, one considers the main production activities, auxiliary production activities, permanent and temporary works, as well as unscheduled or non-standard (in particular, accidental or emergency) types of work. Examples of unscheduled or non-standard works or situations may include:

- temporary changes in the production process;

- breach in the operation of utilities (electricity, water, heat and gas);

- extreme weather conditions;

- emergencies (predicted and / or those that have already taken place)

When identifying hazards, the activity of all persons who have access to the workplace is considered in order to identify the hazards associated with their work and pay attention to their behavior.

The human factor (psychological and physiological abilities and their limitations, human behavior) must be taken into account when assessing hazards and risks of production processes and the production environment in terms of whether this factor can cause wrong actions, 
errors, etc. The human factor must be taken into account whenever one considers the relationships of employees in the team, and has regard to the issues, such as stress, fatigue of the employee, feeling unwell, uncertainty during execution of the works.

When considering the human factor in identification of the hazards, the following shall be taken into account:

- the nature of the works (arrangement of the

workplace, operator's awareness, workload / scope of

Table 2. List of possible hazardous and harmful production factors at grain process enterprises

\begin{tabular}{|c|c|c|}
\hline Type of factor & Hazardous factor (source of hazard) & Possible consequences \\
\hline \multirow[t]{8}{*}{$\begin{array}{l}\text { Mechanical } \\
\text { factors }\end{array}$} & $\begin{array}{l}\text { Moving parts and / or rotating elements } \\
\text { of equipment, tool }\end{array}$ & $\begin{array}{l}\text { Protraction/capturing a piece of clothing or hair } \\
\text { Damage due to friction } \\
\text { Impact }\end{array}$ \\
\hline & Sharp objects, edges, bosses & Cuts, scratches, racoma, puncture wounds \\
\hline & Dust, smoke & $\begin{array}{l}\text { Difficult breathing } \\
\text { Diseases of the respiratory system Reduced vision }\end{array}$ \\
\hline & \begin{tabular}{|l|l|} 
Staying at altitude, high-altitude \\
platform, ladder, etc.
\end{tabular} & Fall from heights, fatigue, dizziness \\
\hline & \begin{tabular}{|l|l|}
$\begin{array}{l}\text { Unsecured cargo or objects over the } \\
\text { surface }\end{array}$ & \\
\end{tabular} & Mechanical injuries caused by falling objects \\
\hline & Split-level, rough or slippery floor & Fall \\
\hline & Increased noise level & $\begin{array}{l}\text { Discomfort, ringing in the ears } \\
\text { Deterioration or loss of hearing }\end{array}$ \\
\hline & Increased vibration noise level & \begin{tabular}{|l} 
Discomfort \\
Neurological disorders. \\
Disorders of joints, vessels. \\
Pain in the spine
\end{tabular} \\
\hline \multirow[t]{5}{*}{ Physical factors } & High voltage & $\begin{array}{l}\text { Electric shock } \\
\text { Electric strike } \\
\text { Burn }\end{array}$ \\
\hline & $\begin{array}{l}\text { High air temperature in the working } \\
\text { area }\end{array}$ & $\begin{array}{l}\text { Heat stroke } \\
\text { Water deprivation }\end{array}$ \\
\hline & $\begin{array}{l}\begin{array}{l}\text { Items or materials with extremely high } \\
\text { or low temperature }\end{array} \\
\end{array}$ & \begin{tabular}{|l} 
Burn \\
Scalding \\
Cold-related injury \\
\end{tabular} \\
\hline & Insufficient local illumination & $\begin{array}{l}\text { Eye strain } \\
\text { Total fatigue }\end{array}$ \\
\hline & Draft & $\begin{array}{l}\text { Hypothermia } \\
\text { Cold }\end{array}$ \\
\hline \multirow[t]{2}{*}{ Chemical factors } & Caustic and poisonous substances, gas & \begin{tabular}{|l} 
Poisoning \\
Irritation of eyes and skin \\
Difficulty breathing, breathlessness \\
Allergic reactions
\end{tabular} \\
\hline & Highly flammable materials & Fire \\
\hline \multirow[t]{2}{*}{ Biological factors } & $\begin{array}{l}\text { Biological and microbiological (viral or } \\
\text { bacterial) pathogens }\end{array}$ & Viral or infectious diseases \\
\hline & Insects, rodents & $\begin{array}{l}\text { Viral diseases } \\
\text { Allergic reactions } \\
\text { Stress }\end{array}$ \\
\hline \multirow[t]{4}{*}{ Human factors } & Non-ergonomics of working place & Discomfort, fatigue \\
\hline & Excessive physical activity & Fatigue, musculoskeletal disorders \\
\hline & Excessive mental load & Fatigue, stress, depression \\
\hline & Monotonous actions & Fatigue, depression \\
\hline
\end{tabular}

works to be performed, physical labor, working modes); - parameters of the working environment (temperature, lighting, noise, air quality);

- human behavior (temperament, habits, relationships in a team); tentiveness);

- physiological potential (biomechanical, anthropometric, physical features of a person).
- psychological potential (cognition ability, at- 
Also, the interaction of the employee and the working environment is considered, for example, whether the employee is able to perform the works assigned to a certain extent and some degree of complexity, whether the workplace meets the anthropometric, physical data of the worker, or whether the work environment negatively affects the employee's general condition and working capacity.

During the identification of the hazards, it is also necessary to consider the cases when the source of hazard is not related to the workplace, but the hazard may affect people in the workplace. When identifying hazards, the following is taken into account:

- hazardous factors that have arisen near the workplace due to work under the control of the enterprise, in particular, this concerns the environmental aspects considered as part of the environmental management system;

- infrastructure, equipment and materials in the workplace, provided both by the enterprise and other persons;

- existing or foreseeable changes in the activity of the enterprise;

- changes in the OSHMS, in particular, temporary changes and their impact on operations, processes, activities,

- any legal obligations relating to the assessment of risks and the introduction of necessary security measures at the enterprise;

- design, project decisions as to the safety of installations, machines and equipment at work sites;

- rational organization of work in the workplace, in particular in terms of adaptation to the worker's capabilities.

Based on the results of identification of the hazards, the following should be at least determined:

- hazard (object, situation or action, or combination thereof);

- a place of hazard (subdivision, site, etc.);

- kind of work, operations, when the hazard

arises;

- workers exposed to risk (in particular their position, occupation), as well as all third parties who have access to the place of hazard.

Risk assessment means the determination of the magnitude of risks, analysis of the possible consequences and the probability of their occurrence, making decision on the acceptability or unacceptability of risks.

Supplementary information may be required for risk assessment, in addition to data determined based on hazard identification, for example:

- detailed information important for risk assessment, place of work;

- distance to another workplace as to its possible dangerous impact;

- professional preparedness and experience of an employee who performs hazardous work;

- toxicological, epidemiological and other data related to human health;

- detailed information on working instructions for carrying out of hazardous works and / or permits executed for hazardous works;
- manufacturer's instructions for operation of the equipment and its maintenance;

- availability and use of safety devices, such as ventilation systems, personal and collective protection equipment;

- detailed information on the adequacy of emergency preparedness procedures, availability of emergency evacuation plans, rescue equipment, etc.;

- data on the duration and frequency of specific works.

Methods of risk assessment are divided into qualitative and quantitative. The qualitative method is to find and identify causes and types of risks. A quantitative method is an assessment of the frequency of risks or the probability of their consequences. The choice of the method is based on the objectives of risk assessment, professional competence, resource requirements, etc.

In most cases, risk can be assessed by means of the methods on the basis of the expert opinions of the specialists.

According to the results of the risk assessment, the magnitude of the identified risk should be established, in particular, the unacceptable risks shall be indicated. This information is used when determining the order of priority of security measures.

According to the results of the risk assessment, the adequacy of the available security measures, the need for their improvement or the introduction of other security measures are determined.

It is required to choose the security measures able to reduce the probability of a potential severity of injury or damage. When choosing security measures, one can use their classification, from measures aimed at the complete elimination of hazards to the measures that provide for the use of personal protective equipment:

- elimination of hazard (for example, replacement of overhead systems by the cables);

- engineering solution for replacement (replacement by less dangerous materials or reduction of energy consumption of the system);

- technical solution (installation of ventilation and aspiration systems, mechanical fencing, blocking, sound notification, etc.);

- signboards, warnings and/or administrative security measures (safety signs, marking of the hazardous zone, warning buzzers/lights, signaling, safety of procedures, equipment inspection, access control, safety systems, labels and work permits, briefings, meetings, conversations, etc.);

- personal protective equipment (safety glasses, headphones, respirators, gloves, etc.).

On a practical level, the grain process enterprise can choose both separate security measure, and a combination of several security measures. If risk can not be eliminated, then it is necessary to consider the risk reduction to an acceptable level, which an enterprise can tolerate, taking into account its legal obligations and its own occupational health policy. When choosing security measures, the following shall be considered:

- regulatory documents in the field of labor protection, which specify the security measures for specific hazards; 
- best practice in the area of labor protection, the latest achievements in this area;

- the need to combine security measures, such as technical means of protection and personal protective equipment;

- the possibility of using collective protection means;

- availability of resources for implementation of a certain security measure;

- the necessity of implementation of preventive maintenance, for example with regard to protective equipment;

- other factors that can affect the security.

When choosing security measures, the actions as to high level or risk and/or proposals for significant risk mitigation shall take precedence over any actions that have a limited benefit from risk mitigation.

Data on identified hazards, hazard-related risks, and security measures taken shall be documented, for example, in the form of a list of hazardous factors and appropriate security measures.

Documented data shall be used during:

- formation and review of labor protection policy;

- setting goals in the area of the labor protection; protection; objects;

- determination of monitoring and measurement

- determination of operational control objects.

Documentation of data makes it possible to compare over time the appropriateness of the introduced security measures, to trace trends in order to improve hazard identification and risk assessment processes.

Thus, the desire to be a competitive, stable and advanced enterprise not only in Ukraine, but also outside, requires from modern grain process enterprises to introduce or reorient the already existing system of labor protection management to a risk-oriented approach, consisting in quantitative and qualitative calculation of the risks for each particular object taking into account all sources, factors and circumstances that contribute to the emergence and development of hazards. This requires not only the development of algorithms, methods and models of risk assessment, but also the appropriate training of specialists, who have competence in the risk-oriented thinking approach in organizing a comprehensive occupational safety system at the enterprise. It is appropriate to create a separate risk management department, whose specialists will deal with the identification of risks, statistical and registration processing of incidents, development and implementation of measures aimed at improving the safety of the enterprise, insurance activities and close cooperation with the labor protection service.

\footnotetext{
REFERENCES

1. [Veb-sayt]. URL: http://uga.ua/calendar/forum-zernopererobnikiv-2018/.

2. [Veb-sayt]. URL: https://dnaop.com/html/34112/doc-\%D0\%94\%D0\%A1\%D0\%A2\%D0\%A3_OHSAS_18001_2010

3. [Veb-sayt]. URL: https://zakon.rada.gov.ua/laws/show/989-2018-\%D1\%80/card3\#Files

4. [Veb-sayt]. URL: https://zakon.rada.gov.ua/laws/show/994_b23. Directive No. 89/391/EEC Council on the establishment of measures to promote the improvement of health and safety of workers.

5. [Veb-sayt]. URL: https://zakon.rada.gov.ua/laws/show/994_062 European Social Charter (revised), Strasbourg, 3.05.1996.

6. DSTU ISO 31000:2018 “Risk management. Guidelines (ISO 31000:2018,IDT)”-K.:2006. - p. 17.

7. [Veb-sayt]. URL: https://zakon3.rada.gov.ua/laws/show/ru/z0397-15/ Provisions on labor protection management system at the power industry enterprises dated 09.02.2015
}

О.О.ФЕСЕНКО, канд. техн. наук, доцент,

В.М. ЛИСЮК, канд. техн. наук, доцент, 3.М. САХАРОВА, ст. викладач

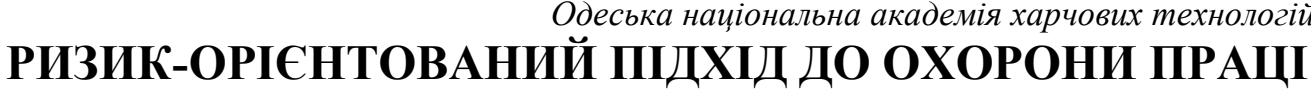
НА ЗЕРНОПЕРЕРОБНИХ ПІДПРИЕМСТВАХ

\section{Анотація}

Стаття присвячена впровадженню ризик-орієнтованого підходу до охорони прачі на підприємствах зернопереробної галузі. Такий підхід є обов'язковим в сучасних умовах згідно Концепџії реформування системи управління охороною праціi. Це передбачає впровадження проактивного принцииу «запобіжних дій» (профілактика небезпечних випадків та ситуачій) замість існуючого реактивного принципу «коригувальних дій» (реагування на небезпечні випадки та ситуаціï). Ризик-орієнтованого підхід у сфері безпеки та гігієни праці є основою для формування нової національної системи запобігання виробничим ризикам.

На зернопереробних підприємствах, які узгодили свою політику з охорони праці з міжнародними стандартами, відбувся зріст і поліпшення відповідальності і компетентній рядових працівників $і$ менеджерів у питаннях безпеки, знизився ризик травмування на робочих місиях.

Удосконалення системи управління охороною праці та ризиками на підприємствах повинно проводитись за ДСТУ ISO 31000:2018 «Керування ризиками. Керівні вказівки (ISO 31000:2018, IDT)». Мета стандарту - зниження виробничих ризиків до прийнятного рівня. Наведені основні етапи процесу керування ризиками.

Ідентифікація небезпек, оцінювання ризиків, визначення заходів безпеки є складовою $і$ невід'ємною частиною такої системи. Це є необхіднім для розпізнання і розуміння небезпек, які можуть виникнути у 
прочесі діяльності підприємства, для оцінювання ризику, який випливає з конкретної небезпеки, $і$ для запровадження заходів по зниженню ймовірності виникнення небезпек.

На підприємствах зернопереробної галузі ідентифікація небезпек полягає у визначенні всіх об'єктів, ситуацій або дій (чи їх поєднання), щуо притаманні діяльності підприємства та несуть потенційну загрозу здоров 'ю та життю працівників. Одночасно розглядають різні види робіт і ситуацій, щзоб виявити небезпеки, які постійно присутні за нормальних умов роботи, а також небезпеки, вплив яких можливий за відхилення від нормальних умов роботи та аварійних ситуацій. Наведені приклади можливих небезпечних чинників на таких підприсмствах.

За результатами оцінювання ризиків визначають адекватність наявних заходів безпеки, потребу в їх поліпшенні чи запровадженні інших заходів безпеки.

Ключові слова: охорона праці, система управління охороною праці, ризик-орієнтований підхід, ідентифікація небезпек, виробничий ризик.

\section{ЛІТЕРАТУР}

1. Електронний ресурс. Режим доступу: http://uga.ua/calendar/forum-zernopererobnikiv-2018/.

2. Електронний ресурс. Режим доступу: https://dnaop.com/html/34112/doc$\% D 0 \% 94 \% D 0 \% A 1 \% D 0 \% A 2 \% D 0 \% A 3$ OHSAS 180012010.

3. Електронний ресурс. Режим доступy: https://zakon.rada.gov.ua/laws/show/989-2018-\%D1\%80/card3\#Files .

4. Електронний ресурс. Режим достуnу: https://zakon.rada.gov.ua/laws/show/994 b23 . Директива № 89/391/CEC Paди щьоо запровадження заходів заохочення поліпшення безпеки та охорони здоров\&\#39;я прачівників на роботі.

5. Електронний ресурс. Режим доступу: https://zakon.rada.gov.ua/laws/show/994 062 . Свропейська соиіальна хартія (переглянута). Страсбург, 3.05.1996 p.

6. ДСТУ ISO 31000:2018 «Керування ризиками. Керівні вказівки (ISO 31000:2018, IDT)». - К.: 2006. - 17 c.

7. Електронний ресурс. Режим доступy: https:// zakon3.rada.gov.ua/laws/show/ru/z0397-15/. Положення про системy управління охороною праці на підприємствах електроенергетики від 09.02.2015.

Надійшла 14.02.2019. Рецензія 19.02.2019.

До друку 22.02.2019.

Адреса для переписки:

вул. Канатна, 112, м. Одеса, 65039

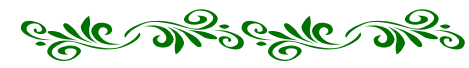

A. P. BOCHKOVSKYI ${ }^{1}$, PhD, ass. professor, N. Yu. SAPOZHNIKOVA ${ }^{2}$, PhD, senior lecturer ${ }^{1}$ Odessa National Polytechnic University, Odessa, Ukraine ${ }^{2}$ Odessa National Academy of Food Technologies, Odessa, Ukraine Ukraine

\section{ASPECT OF MINIMIZATION AREAS OF «HUMAN FACTOR》 IN LABOR SAFETY}

Abstrakt

The article analyzes well-known semantic interpretations of the term "human factor" in the context of the evolutionary development of the safety component in "man-machine-environment" systems. It has been ascertained that single, recognized by law term "human factor" still does not exists, but the majority of researchers attribute this phenomenon to the human psycho-physiological reaction to changes in the environment.

It is noted that this approach is erroneous because the manifestations of "human factor" at the individual level of each person should be considered in the context of the features of its three main components - biological, social and informational. The trends of the evolutionary development of the technosphere and the analysis of statistical data on occupational accidents, as well as industrial breakdowns and disasters, prove the need to introduce positive changes at the level of the "human factor" components. First of all, it concerns the information component, as the development of technologies over the past decade is far ahead of the level of training in the field of occupational safety, which does not allow maintaining the required level of occupational safety and labor culture in the conditions of a new range of previously unknown hazardous and harmful production factors.

It was emphasized that necessary positive changes in the components of the "human factor" should be implemented as a part of the concept of sustainable humanity development, which provides for the development of three interrelated areas: economic, social and spiritual growth of society. Thus, basic directions that will minimize the negative effects of the "human factor" within functioning of the future complex systems "man-machine-environment", are to increase the level of motivation for safe human behavior at production facilities and to form safety priorities over economic outcomes of enterprise's activity. The possibility to implement such directions directly depends on the implementation of the relevant reforms in the system of secondary, vocational and higher education, as well as occupational safety and industrial safety regulatory framework in Ukraine.

Keywords: labour safety, human factor, sustainable development, "man-machine-environment" systems, industrial safety. 